\title{
Indicators for Sustainable Redevelopment of Cultural Landscapes - Huangpu Veterans Quarter in Taiwan
}

\author{
Kuo-Wei Hsu, Nai-Chia Chao, and Jhong-Ping Xie
}

\begin{abstract}
Overdeveloped land, misused resources, limited and fast development landscape in urban Taiwan, are problems and challenges government continuously facing and avoiding; Re-utilizing underdeveloped and limited landscape in Taiwan is an important subject. Taiwan Kaohsiung obtains and preserves the largest Military Dependents' Village (MDV) landscape in Taiwan; an important, unique, and valuable historic cultural landscape affiliate historical, military and ethnic group living culture village. This study reviewed sustainable development and village preserve literature, and propose re-development structural framework of MDV through two-stage experts' questionnaire survey.

The first stage utilized the Fuzzy Delphi Method, which focuses on impact factors, and the second, the AHP Method, deals with performance factors. The results indicate that the key impacts on the cultural landscape sustainability redevelopment strategies for Huangpu MDV were its cultural value, historic site, and maintenance management.
\end{abstract}

Index Terms-Eco-village, Huangpu veterans quarter, cultural landscapes.

\section{INTRODUCTION}

Along with the aggravate urban expansion, land scarcity, and resource deficiency, urban sustainability development faces critical challenges. Human environment is the core value, concept, principle, and method of sustainability development. Scarce landscape, over-populated, limited living space, and continuous population increase, reutilizing unused lands are vital.

Taiwan Veterans' Village (Quarter) is a significant and special historical heritage, and also an important cultural asset. After China's civil war, soldiers and citizens from different provinces were forced to settle in Taiwan. Statistic shows, from 1945 to 1950, nearly 2 million civilians and soldiers transfer with Kuomintang (KMT) government to Taiwan from Mainland China impacted with dramatic population change to Taiwan society. As the KMT took over Japanese fortress and facilities, KMT soldiers and dependents moved into Japanese dorm successively; however, since dorms were limited, it was first provided to higher rank officers and administration staff, under lack of supply of living space, KMT soldiers and citizens gathered in Taipei, Keelung, and Kaohsiung urban area [1].

The development of Military dependent village can be classified in 5 steps: 1949-1955, public military village were constructed with poor material under the concept of "it is a temporary living space"; 1956-1967, village were planned,

Manuscript received October 14, 2020; revised January 20, 2021.

The authors are with Chaoyang University of Technology 168, Jifeng E. Rd., Wufeng District, Taichung, Taiwan (e-mail: joyandbigcat@gmail.com). constructed and expanded around Taiwan; 1967-1980, decline of military village construction, from public to private ownership. 1981-1995 end of military village construction, the old military dependent village were reconstructed; After 1996, as the "Act for Rebuilding Old Quarters for Military Dependents" were introduce, the re-development plan went under government management from military authority [2].

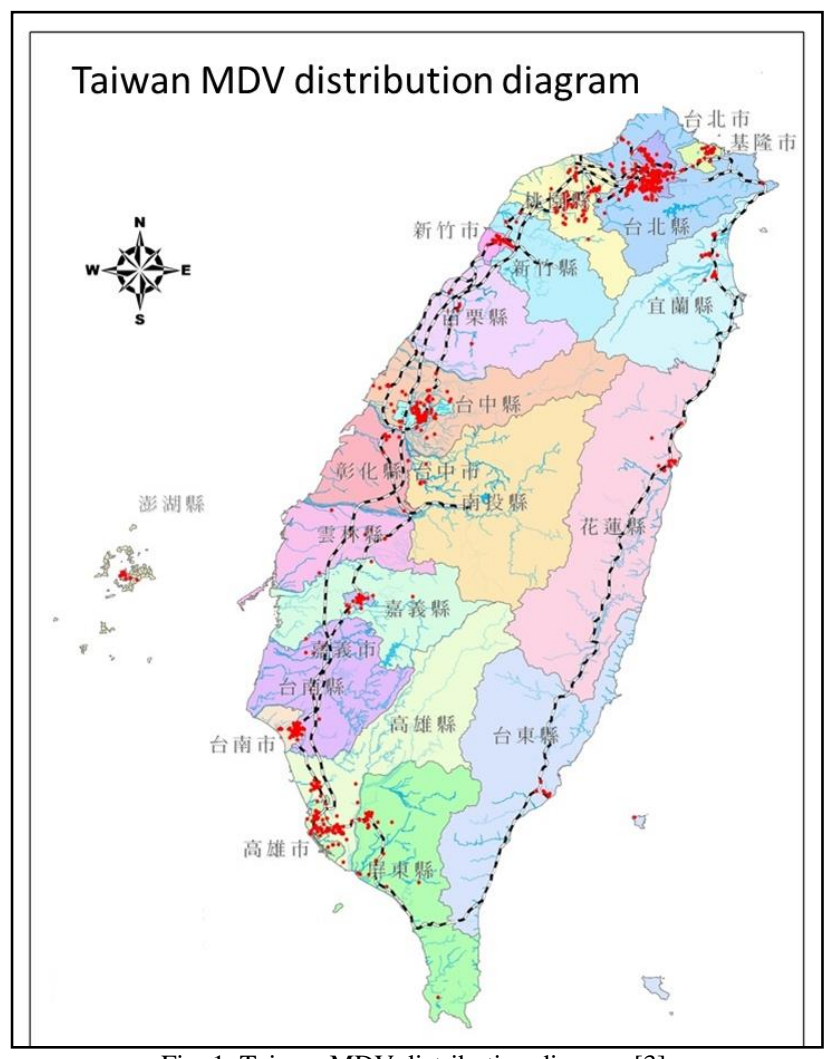

Fig. 1. Taiwan MDV distribution diagram [3].

Military Dependents Village (MDV) were mostly located on the center of urban zone or near the military/army headquarter; Taipei city consisted largest quantities and densities of MDV, which Kaohsiung had the most MDV households numbers [3]. Due to MDV special living space and diverse residents, the half-closed living system framed and formed a distinct and rare culture in Taiwan society. As time passes on, this unique cultural atmosphere diminishes and the originated space structural started to change.

Thus, to preserve this extraordinary historical and human enclaved cultural landscape space, Taiwan government, Ministry of National Defense, and Ministry of Culture's cooperated to proceed with the preservation and revitalization of MDV.

Many MDV are sited in the core of urban area, with wide land, and comfort living spatial environment and atmosphere 
status preserved from the old era; The primary purpose of this research study is to determine important factors that need to be taken under consideration on urban MDV sustainable development.

\section{PROCEDURE FOR PAPER SUBMISSION}

\section{A. Sustainable Development}

Sustainable Development should be prioritized on top of ecological habitat environment, economic benefits, social atmosphere, and cultural characteristics the basic fundamental concepts; a place, city or community, served for this generation and future generation's basic need, choice of freedom, self-respect \& self-discipline environment by adopting systematic, integrated, and prioritized strategies action plans [4]

The core concept is to "provide to anyone, at any time, at any place, the opportunity of dignity living style at current society"; Sustainable development involves 3 subjects: economic, ecological and social through 5 diverse aspects: economic production, ecology environment, social living, and cultural preservation, and management mechanism [5], [6].

By extending further the core concept of sustainability development, Eco-Village is introduced to the public. According to the Global Ecovillage Network evaluation standard, eco-village is defined and determinate only when ecology environment, social relationship, and economic, culture, and mental living possesses all with sustainability approach [7].

Under different and diverse circumstances, Eco-Village demonstrates different models such as eco-system, rural, or urban sustainable development community. Communities located central cities, are the early development, which is characterized by high-density living spacing, complex formation and mix usage of different soils, and high intensity, indeed community spacing is developed, thus the eco-environment resource is rare [8] .

\section{B. MDV Re-development}

Prioritizing MDV re-utilizing analysis, accompanied in detailed discussion on cultural assets' preservation, re-vitalizing and re-utilizing, and cultural creativity industrial development approach. Re-development, a word commonly used on urban environments, not limited only to cultural assets as a single subject, but also under consideration of environmental context and social culture, a broader and macro view approach and arrangement.

Re-development, a wording utilizing different methods and approaches by consolidating and accumulate the historical passage and resources that best demonstrate, present, and establish local custom \& tradition.

Content should include area renovation, existing resource utilization, local characteristic and re-establish, local role development, and feature re-setting. Re-novate, re-develop, or re-generate are approaches used in solving urban problem and urban environment re-built planning [9], [10].

Back re-development researches focus on the concept of improving urban environment, throughout a series of evolution change, new subject was introduced. From land re-utilizing to today's emphasis on co-exist of environmental and functional and economic recovery re-development [11].

Regard urban development actual operation, from urban planning \& design point of view, extend the vacant space and exploit flooring from the existing lot, elevate to urban scale perspective by integrating historic meaning, great commercial zone, and adopting misused land cluster. Following approaches are re-development strategies: [12]

1) Integrating public space resource

2) Implementing living and cultural activities

3) Establishing urban structure space sequence

4) Strength local landscaping and preserving general urban fabric.

\section{HUANGPU MDV}

Huangpu MDV is painted with 3 different eras, Japanese colonization, KMT era, and today's inhabit to protect era, demonstrating its significant and historical conflict. Huangpu MDV originated in Japanese construction with single housing or semi-detached housing structure building for Japanese military usage during WWII. Upon the arrival of KMT government, military \& dependent moved in; under dependents' living and spacing need, originated Japanese construction method, buildings ware divided and expanded to meet the demand, therefore, MVD formed a distinct combination of Japanese construction and Chinese living style atmosphere. In 2014, Kaohsiung ministry of culture introduced and offered inhabit to protect project, under undamaging and preserving the existing construction structural MVD to personal or small business groups, in helping Huangpu MDV restoration and revitalization.
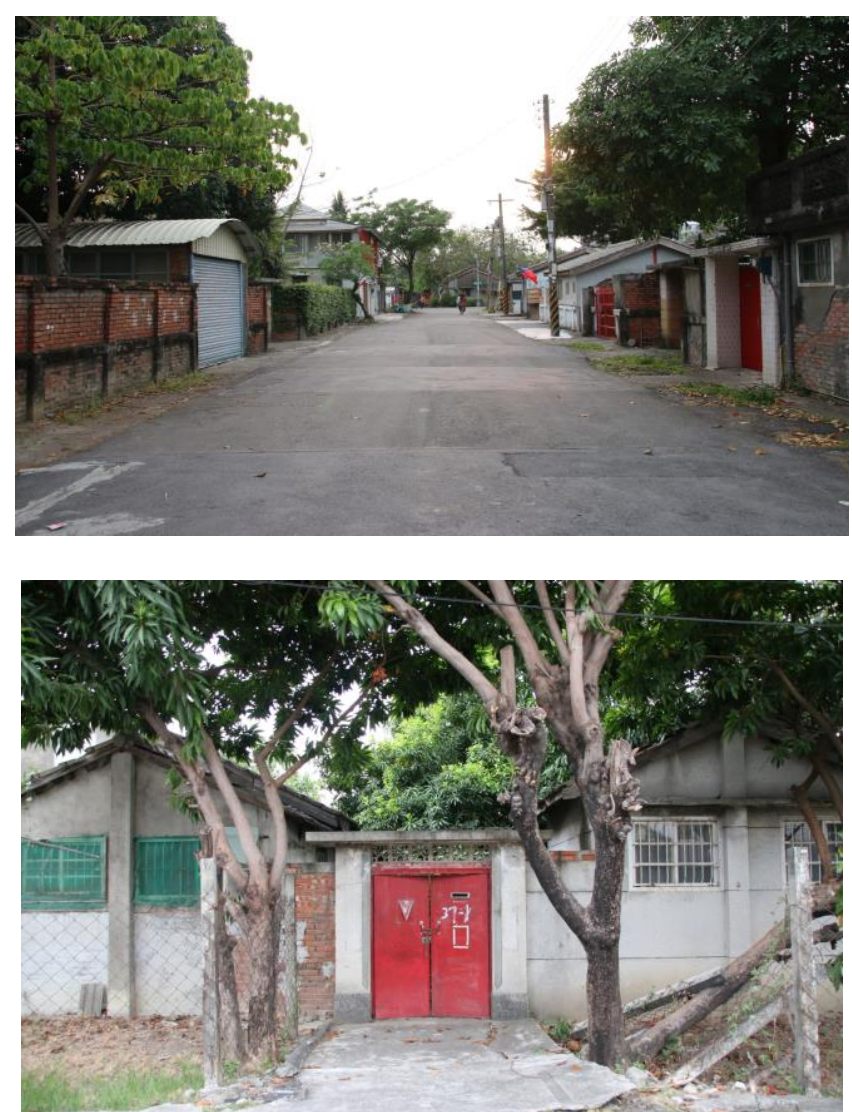

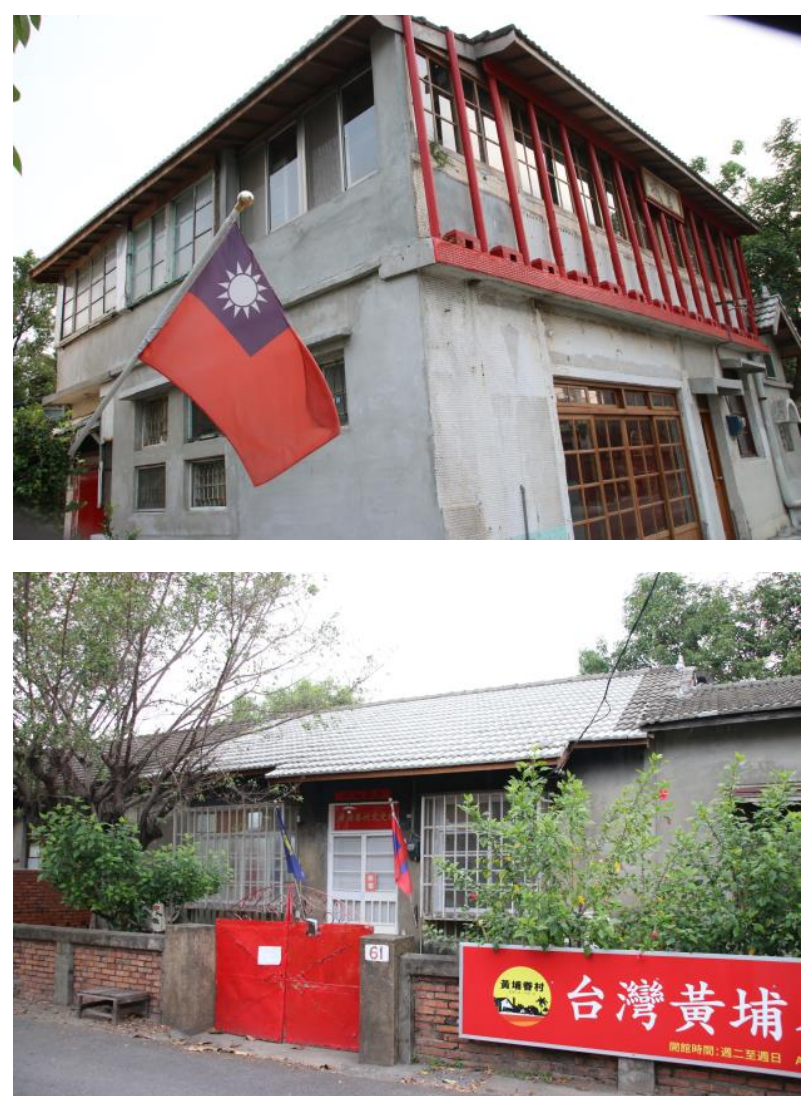

Fig. 2. Status of Huangpu veterans quarter.

Inner Huangpu village, roads were designed as fishbone road traffic structure format, central axis runs through Chengzheng Elementary School; on west and east side of central axis it extends six lanes, west lanes are connected with Weiwu road, as the east land are joint with the residential area. There are a total of 74 Governor-Generals' (Japanese colonization) standard construction buildings, among 10 are single and 64 semi-detached housing; unfortunately, 4 building construction were bombed by US air force during WWII. One of the building were completely removed and reconstructed which it has lost is originate architecture structure, leaving a total of 69 complete Governor-Generals' (Japanese) standard construction buildings. In 2013, the Ministry of Culture announced 43 building architecture was file as cultural landscape managed by the ministry. As for the remaining building were supervise under Ministry of Defense.

\section{MATH}

Through literature review, to form a sustainable village, aspects of environment, economy, and culture ought to be associate within each other, at the same time with cooperation of village's uniqueness, to create and bring out self-brand development. Therefore, generating ecovillage development's aspects into Taiwan's Huangpu Dependent Village, this research concludes that to develop and transform Huangpu New Village into an ecovillage in the future contains three analysis indicators: Social Culture, Spacing Environmental and Economic Beneficial. The Social Cultural aspect summarizes 3 impact factors as MDV military's cultural value, public participation and social identity; the Spacing Environmental aspect categorizes according to the historical development context and environmental characteristics of the space and summarizes 3 factors as historical place, living environment and natural landscape;

Economic Beneficial aspect covers factors as maintenance management, operation and development, and local marketing. Through the formulation of the factors, the fuzzy Delphi method (FDM) is used, through the under valuable opinions provided by experts and scholars to summarize the impact factors, then by utilizing the AHP method to rank the factors, favors future discussion of Huangpu New Village sustainable development.

TABLE I: THE IMPACT FACTORS OF ECOVILLAGE REDEVELOPMENT

\begin{tabular}{|c|c|c|}
\hline $\begin{array}{c}\text { Perspec } \\
\text { tive }\end{array}$ & $\begin{array}{l}\text { Analysis } \\
\text { indicators }\end{array}$ & Description \\
\hline \multirow{3}{*}{ 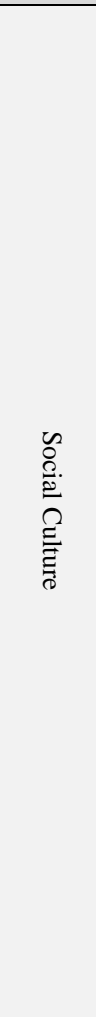 } & $\begin{array}{l}\text { MDV Cultural } \\
\text { Value }\end{array}$ & $\begin{array}{l}\text { 1. Huangpu Village was originated } \\
\text { designed as Japan Military dormitories } \\
\text { during Governor-Generals' period and } \\
\text { was the first village used as MDV after } \\
\text { KMT government retreat to Taiwan; } \\
\text { Architecture buildings remained } \\
\text { Japanese style structure, recording } \\
\text { transition of time, consisting eventful } \\
\text { historic passage and preservation value. } \\
\text { 2. MDV living had formed from diverse } \\
\text { multi-cultural merge through time and } \\
\text { environment context. }\end{array}$ \\
\hline & $\begin{array}{c}\text { Resident } \\
\text { Participation }\end{array}$ & $\begin{array}{l}\text { 1. Early resident of MDV were military } \\
\text { and dependents, who shown strong } \\
\text { patriotism and political } \\
\text { acknowledgment, thus under insular and } \\
\text { exclusive sense of superiority, it created } \\
\text { a strong bond and group cohesiveness } \\
\text { among residents. }\end{array}$ \\
\hline & $\begin{array}{c}\text { Community } \\
\text { Acknowledgem } \\
\text { ent }\end{array}$ & $\begin{array}{l}\text { 1. Respect community residential } \\
\text { perspective and demand and seek } \\
\text { community development consensus and } \\
\text { approval during an open and transparent } \\
\text { process. Assisting the establishment of } \\
\text { civil society fundamental environment, } \\
\text { cultivate community participation on } \\
\text { public issues and independency with } \\
\text { adequate expert resources. }\end{array}$ \\
\hline \multirow[t]{2}{*}{ 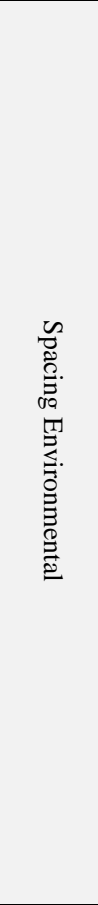 } & Historic Site & $\begin{array}{l}\text { 1. MDV, a site with complicated historical } \\
\text { involvement, recorded and proved } \\
\text { Taiwan's past and today's social } \\
\text { development and historic context; it } \\
\text { also witnesses Taiwan's time-and-space } \\
\text { background and political ecology; it } \\
\text { should be preserved the unique historic } \\
\text { passage and significance. } \\
\text { 2. Local existence cultural context } \\
\text { environment ought to be respected by } \\
\text { new residents; Connecting innovation } \\
\text { and tradition is the key, changing the } \\
\text { site is not the main purpose, but to pass } \\
\text { on and bring back the historic passage } \\
\text { memories back to people and provide an } \\
\text { exploration trail of local culture. }\end{array}$ \\
\hline & $\begin{array}{l}\text { Living } \\
\text { Environment }\end{array}$ & $\begin{array}{l}\text { 1. Huangpu Village architecture was } \\
\text { originated designed as Japanese style } \\
\text { structure mostly single housing or } \\
\text { semi-detached housing; After KMT } \\
\text { settled in, due to different living } \\
\text { methods and demand for space usage, } \\
\text { expansion, and separation on the } \\
\text { originated Japanese construction design } \\
\text { derivatived Japanese architecture }\end{array}$ \\
\hline
\end{tabular}




\begin{tabular}{|c|c|c|}
\hline $\begin{array}{l}\text { Perspec } \\
\text { tive }\end{array}$ & $\begin{array}{l}\text { Analysis } \\
\text { indicators }\end{array}$ & Description \\
\hline & & $\begin{array}{l}\text { building merge Chinese living a unique } \\
\text { scenario. }\end{array}$ \\
\hline & $\begin{array}{c}\text { Settlement and } \\
\text { Residential } \\
\text { Spatial }\end{array}$ & $\begin{array}{l}\text { 1. Huangpu village community structured } \\
\text { in fishbone format which can be } \\
\text { categorized as high density populated } \\
\text { and high defensive community model. } \\
\text { 2. The community contains large green } \\
\text { coverage with broad-leaved wood } \\
\text { planted along both sides of the road. }\end{array}$ \\
\hline \multirow{3}{*}{ 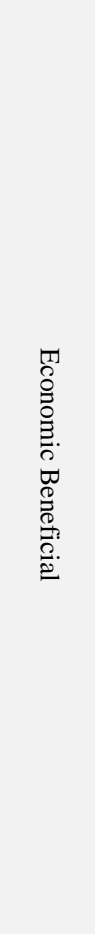 } & $\begin{array}{l}\text { Maintenance } \\
\text { Management }\end{array}$ & $\begin{array}{l}\text { 1. Implementing inhabit to protect project, } \\
\text { Huangpu Village cultural space were } \\
\text { preserved under government's } \\
\text { assistance on innovating new living } \\
\text { system, infrastructure, and public space } \\
\text { maintenance, increased its investment } \\
\text { value and new industry settled to } \\
\text { improve economic development }\end{array}$ \\
\hline & $\begin{array}{l}\text { Development } \\
\text { Operation }\end{array}$ & $\begin{array}{l}\text { 1. Through government financial } \\
\text { resources by offering opportunities for } \\
\text { private investment to public } \\
\text { construction and utilities in favor of } \\
\text { environmental improvement creating a } \\
\text { positive cycle of new investments. } \\
\text { Combine homestay living and } \\
\text { experience facilities can increase and } \\
\text { benefit Huangpu Village's development } \\
\text { economic. }\end{array}$ \\
\hline & $\begin{array}{c}\text { Local } \\
\text { Marketing }\end{array}$ & $\begin{array}{l}\text { 1. By revitalizing local economies, } \\
\text { creating and involving diverse } \\
\text { industrial investment will offer more job } \\
\text { opportunities in Huangpu Village. } \\
\text { Introducing \& enhancing MDV cultural } \\
\text { atmosphere will attract more activities } \\
\text { held in the village and tourism. }\end{array}$ \\
\hline
\end{tabular}

Re-Development evaluation factor of Huangpu Village, followed by the AHP method as the basis. Considering Huangpu's Village uniqueness and normal MDV spacing, architect, and cultural difference, through Huangpu Village's literature research, initial drafting on sorting the impact factor of Huangpu Village's 3 major factors, social-cultural factor, space environment factor, economical factor.

TABLE II: THE IMPACT FACTORS OF ECOVILLAGE REDEVELOPMENT ANALYSIS

\begin{tabular}{|c|c|c|c|}
\hline Target & Dimension & Impact Factor & $\begin{array}{l}\text { Fuzzy Delphi } \\
\text { ( Gi ) }\end{array}$ \\
\hline \multirow{9}{*}{$\begin{array}{l}\text { Indicators for } \\
\text { Sustainable } \\
\text { Redevelopmen } \\
\text { t Cultural } \\
\text { Landscapes }\end{array}$} & \multirow{3}{*}{ Social Cultural } & $\begin{array}{l}\text { MDV Cultural } \\
\text { Value }\end{array}$ & 7.67 \\
\hline & & $\begin{array}{l}\text { Resident } \\
\text { Participation }\end{array}$ & 6.57 \\
\hline & & $\begin{array}{l}\text { Community } \\
\text { Acknowledgement }\end{array}$ & 6.70 \\
\hline & \multirow{3}{*}{$\begin{array}{l}\text { Space } \\
\text { environment }\end{array}$} & Historic Site & 7.83 \\
\hline & & $\begin{array}{l}\text { Living } \\
\text { Environment }\end{array}$ & 7.67 \\
\hline & & $\begin{array}{l}\text { Settlement and } \\
\text { Residential Spatial }\end{array}$ & 6.75 \\
\hline & \multirow{3}{*}{$\begin{array}{l}\text { Economic } \\
\text { Beneficial } \\
\text { Factor }\end{array}$} & $\begin{array}{l}\text { Maintenance } \\
\text { Management }\end{array}$ & 7.83 \\
\hline & & $\begin{array}{l}\text { Development } \\
\text { Operation }\end{array}$ & 7.82 \\
\hline & & Local Marketing & 7.67 \\
\hline
\end{tabular}

TABLE III: THE DIMENSIONS RANKED BY WEIGHTS

\begin{tabular}{|c|c|c|c|c|c|}
\hline Dimension & Weight & $\begin{array}{l}\text { Rank } \\
\text { ing }\end{array}$ & Impact Factor & $\begin{array}{r}\text { Factor } \\
\text { weight }\end{array}$ & $\begin{array}{l}\text { Ran } \\
\text { king }\end{array}$ \\
\hline \multirow{5}{*}{$\begin{array}{l}\text { Social } \\
\text { Cultural }\end{array}$} & \multirow{5}{*}{0.3436} & \multirow{5}{*}{1} & MDV Cultural Value & 0.2052 & 1 \\
\hline & & & Resident & 0.0501 & 9 \\
\hline & & & Participation & & \\
\hline & & & Community & 0.0883 & 7 \\
\hline & & & Acknowledgement & & \\
\hline \multirow{4}{*}{$\begin{array}{l}\text { Space } \\
\text { environme } \\
\text { nt }\end{array}$} & \multirow{4}{*}{0.3251} & \multirow{4}{*}{3} & Historic Site & 0.1480 & 2 \\
\hline & & & Living Environment & 0.1107 & 4 \\
\hline & & & Settlement and & 0.0663 & 8 \\
\hline & & & Residential Spatial & & \\
\hline \multirow{5}{*}{$\begin{array}{l}\text { Economic } \\
\text { Beneficial } \\
\text { Factor }\end{array}$} & \multirow{5}{*}{0.3313} & \multirow{5}{*}{2} & Maintenance & 0.1157 & 3 \\
\hline & & & Management & & \\
\hline & & & Development & 0.1070 & 6 \\
\hline & & & Operation & 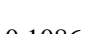 & \\
\hline & & & Local Marketing & 0.1086 & 5 \\
\hline
\end{tabular}

\section{SETtLEMENT AND RESIDENTIAL SPATIAL}

The concept of sustainability is not a set of indicative actions, but a new evaluation basis to resources, environment, social, fairness, and topics that brought into consideration.

Taiwan's Ecovillage mostly focus on community development, rare on reuse of cultural asset space as this research.

MDV is a spacial living space with special cultural meaning to Taiwan; it represents an important part of Taiwan's modern history, and its spatial atmosphere which has gradually faded and daily living culture has disappeared through time evolution. How to preserve the unique spatial vocabulary and living culture of the MDV is one of the most considerable topic by Ministry of Culture of Taiwan.

Furthermore, urban spatial, spatial demand and function continuous change as time and population structure changes; MDV located inner urban area, becomes a valuable hinterland for a greater demand for spatial demand in the urban environment. Therefore, how to reach an balance between redevelopment and preserving the existing unique culture of ecovillage of Taiwan MDV has always been in discussion.

Hence, throughout this research, for Taiwan MDV to develop into ecovillage, besides 3 major aspects, Preservation of culture is also one of the key aspects of sustainable development. For ecovillage sustainable development, local culture preservation, not only set as principle for future development, but also stimulate different aspect on operation and mechanism management to become an ecovillage with cultural connotation and characteristic.

this study explores whether under the factors of sustainable redevelopment, in such special culture under settlement and residential spatial, differs on the development impact factor. so we attempts to obtain expert consensus on the impact factors through FDM, and at the same time, concludes that the preservation of cultural values and the maintenance of historical sites are prioritized than other factors on urban MDV redevelopment. At the same time, as the Huangpu New Village promotes the "Inhabitant to protect" project, the maintenance management, and operation mechanism must be taken into primary consideration; further investigation on Huangpu MDV historical culture, from actual spatial distribution, through consideration on village's existing environment heterogeneous \& homogeneity, to 
reach balance in historical cultural preservation and future demand management. Under environmental development, through resident participation and implementing community autonomy, establishing a sustainable development of safe, healthy, and local characteristic Taiwan's MDV.

\section{CONFLICTS OF INTEREST}

The authors declare no conflict of interest.

\section{AUTHOR CONTRIBUTIONS}

Supervision, K.-W.H.; Writing - original draft, N.-A.C.; Writing - review \& editing, N.-A.C \& J.-P. X..

\section{REFERENCES}

[1] S. Chen, B. Mulgrew, and P. M. Grant, “A clustering technique for K.C. $\mathrm{Li}$, "Historical formation and social differences of Chuan-Tsuan in Taiwan: A comparison of registered and self-supported military communes," Taiwanese Journal of Sociology, 2015-09-01, issue 57, pp. 129-172, September 2015.

[2] Y. H. Wang, "The study of cultural assets reuse policies towards military kindred village -air force san-chong village 1," Tamkang History Review, issue 30, pp. 51-83, September 2018.

[3] Taiwan National Science Council Military Villages digital archive GIS [Online]. Available: https://museum02.digitalarchives.tw/teldap/2008/twgisonline/www.tw gisonline.com/index-2.html

[4] J. H. Spangenberg, "Reconciling sustainability and growth: Criteria, indicators, plicies," Sustainable Development, vol. 12, pp. 74-86, 2004

[5] M. Munasinghe, "Environment economics and sustainable development. Washington,” Washington, D.C.: World Bank, 1993
[6] T.-S. Chiang, L. Y. Chang, "Sustainable community indicators system-building of governance capacity," Taiwan Foundation for Democracy, vol. 11, no. 4, pp. 37-83, December 2014.

[7] Global Ecovillage Network. [Online]. Available: https://ecovillage.org/projects/what-is-an-ecovillage/

[8] Y. J. Lee, "Regulations of urban sustainable communities: The new trend of sustainable development of the country," Newsletter for Research of Applied Ethics, vol. 41, pp. 48-57, February 2007.

[9] M. J. Chen, "Taipei city Ximen downtown area and Wanhua station area redevelopment plan," Taipei Open Space Culture and Education Foundation, 1991.

[10] X. B. Lin, "Research on the Redevelopment of the old city center and promotion of tourism strategies - Taking Beigang as an example," Master's thesis of National Cheng Kung University Urban Planning Institute, 1995.

[11] C. D. Syu, "A research on redevelopment issues of the historic street culture - Case study of San-Sia historic street," National Taipei University Institute of Folk Art Master Thesis, 2009.

[12] L. C. Lai, "A study of the redevelopment of urban unoccupied space under the concept of glocalization: A case study of the historical main street in the urban core of Tainan City," Master's thesis of National Cheng Kung University Urban Planning Institute, 2004.

Copyright (C) 2021 by the authors. This is an open access article distributed under the Creative Commons Attribution License which permits unrestricted use, distribution, and reproduction in any medium, provided the original work is properly cited (CC BY 4.0).

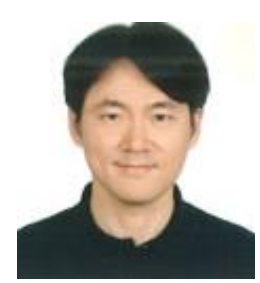

Kuo-Wei Hsu is a professor at the Chaoyang University of Technology, Department of Landscape and Urban Design, in Taichung, Taiwan. He was the head of the Department of Urban Planning and Landscape Architecture, between the year 1999 and 2005. His expertise is financial analysis, urban planning, urban design, real estate and land development. 